\title{
Italian-Australian Internment Life Stories: Recapturing Salvatore Ragonesi between the Public Record and Family Memories
}

\author{
Catherine Dewhirst, Claire Kennedy and Sam Ragonesi
}

\begin{abstract}
Since the Archives Act of 1983 Australia's World War II internees have had access to their wartime files, yet little attention has focused on whether they and their families have consulted these records, or on their responses to them. From the early 2000s historians and archivists began discussing the need for combining private oral testimony with official records as part of a wider discourse on the importance of life stories for deepening knowledge about the past. This article explores the impact of a father's official internment records on his son, through the son's sharing of memories, lived experience and his reactions to official documents, in order to provide a more complete story of his father's internment and life than either the public record or the oral testimony alone can produce. We argue that Sam Ragonesi's oral testimony, especially concerning his encounter with Salvatore Ragonesi's official records, contributes to a greater shared understanding of experiences of war on the home front by integrating social, cultural and family dimensions hidden from Ragonesi's public history. In this way intergenerational experiences help both to contest the collective image of internment and create a more complex picture of the War.
\end{abstract}

Between 1939 and 1945 approximately 7,000 foreign-born residents were interned in Australia, including over 1,500 naturalized British Subjects. ${ }^{1}$ The most recent figures show that 4,855 Italian civilians represented the largest 'enemy-alien' group, and over 20 per cent of the Italian-born population. ${ }^{2}$ Since the Freedom of Information Act of 1982 and the Archives Act of 1983 it has been possible to access individuals' official internment records, which has resulted in a growing body of scholarship. ${ }^{3}$ Such access also led to political recognition

\footnotetext{
${ }^{1}$ Ilma Martinuzzi O'Brien in Mario Sardi, The Internment Diaries of Mario Sardi, Ilma Martinuzzi O'Brien, ed. (Alphington, 2013), p.185.

2 On the overall figures, see Klaus Neumann, In the Interest of National Security: Civilian Internment in Australia during World War II (Canberra, 2006), p.7. Queensland accounted for almost half $(2,413)$ of the Italians interned, and over 25 per cent came from the North Queensland sugarcane farming towns of Ingham and Innisfail. Martinuzzi O'Brien in Sardi, The Internment Diaries, p.185; Ilma Martinuzzi O'Brien, "Italians in Ingham and Innisfail in World War II: Selective and Not Mass Internment?", Spunti e Ricerche, Vol. 24 ([2009] 2011), pp.75-76, 87.

${ }^{3}$ See: Konrad Kwiet, "'Be Patient and Reasonable!' The Internment of German-Jewish Refugees in Australia", Australian Journal of Politics and History, Vol. 31, 1 (1985), pp.61-77; Raymond Evans, Loyalty and Disloyalty: Social Conflict on the Queensland Homefront, 1914-1918 (Sydney, 1987); Gerhard Fischer, Enemy Aliens: Internment and the Homefront Experience in Australia, 1914-1920 (St Lucia, 1989); Kay Saunders, “'Discovering' the Subversive and the Saboteur: The Disjuncture between Official Records of Internment Policy and Practice and the Remembered Experiences of Internees in Australia in the Second World War", Oral History Association of Australia Journal, Vol. 13 (1991), pp.1-11; Richard Bosworth and Romano Ugolini, eds, War, Internment and Mass Migration: The Italo-Australian Experience, 1940-1990 (Rome, 1992); Margaret Bevege, Behind Barbed Wire: Internment in Australia during World War II (St Lucia, 1993); Yuriko Nagata, Unwanted Aliens: Japanese Internment in Australia (St Lucia,
} 
of the "grave injustices" inflicted on internees of Italian origin. ${ }^{4}$ Klaus Neumann describes the whole episode as "the nation's dark underside during World War II", a history that is largely unknown to the general public. ${ }^{5}$

The content of the official records is mostly limited to serving the government's purpose of documenting formal procedures to restrict the activities of 'enemy aliens' in order to protect national security. Although the records occasionally offer valuable insight into the context of an individual's case, evidence of internees' voices and perspectives tends to be incidental (found, for example, in transcripts of appeal hearings or when personal letters are included). In addition, widespread reluctance among internees to talk about their incarceration after release ${ }^{6}$ suggests few family members were aware of their relatives' experiences. Very little is known about whether internees and their families have accessed the archives, or about their responses to the contents, and whether such encounters can instigate a wider sharing of memories.

This article explores the experience of one family whose members talked freely about internment and later accessed the official records. We seek not only to develop an understanding of the impact of the encounter with the records, but in so doing to produce a more complete story of one internee than either the archival records or his son's oral testimony alone can offer. We argue that descendants of internees can contribute valuable social, cultural and family dimensions to Australia's internment history, and that a descendant's engagement with the public record may offer a stronger means of capturing the layers of an internee's life story than recording oral history in isolation. Indeed, families and communities hold valuable insights for contesting internment history, contributing significant information and revealing longitudinal effects of wartime involvement.

Integrating intergenerational experiences into Salvatore Ragonesi's official internment history enables the inclusion of previously hidden features of his experiences and the effects of war on the home front. As Neumann recognized, little is known about this episode more widely, let alone the personal stories of

1996); Kay Saunders and Roger Daniels, eds, Alien Justice: Wartime Internment in Australia and North America (St Lucia, 2000); Franca Iacovetta, Roberto Perin and Angelo Principe, eds, Enemies Within: Italian and Other Internees in Canada and Abroad (Toronto, 2000); Cate Elkner, Ilma Martinuzzi O'Brien, Gaetano Rando and Anthony Cappello, eds, Enemy Aliens: The Internment of Italian Migrants in Australia during the Second World War (Ballarat, 2005);

Neumann, In the Interest; Joan Beaumont, Ilma Martinuzzi O'Brien and Mathew Trinca, eds, Under Suspicion: Citizenship and Internment in Australia during the Second World War (Canberra, 2008); Mia Spizzica, ed., Hidden Lives: War, Internment, and Australia's Italians (Brisbane, 2018).

4 Politicians Bob Woods and Con Sciacca, 1991, cf. Bevege, Behind Barbed Wire, p.xx.

${ }^{5}$ Neumann, In the Interest, p.86. One part of this history that has been brought to the attention of the general public is the story of Jewish-German refugees, known as the Dunera Boys. See: Klaus Neumann, Across the Seas: Australia's Response to Refugees: A History (Collingwood, 2015), pp.82, 98-100; Ken Inglis, "In search of Henry Mayer", Australian Journal of Political Science, Vol. 51, 1 (2015), pp.7-24.

${ }^{6}$ Don Dignan in Osvaldo Bonutto, A Migrant's Life (St Lucia, [1963] 1994), p.x; Neumann, In the Interest, p.86. 
internees. Indeed, the general public tends not to have a contextual understanding of the political and administrative procedures, so the records can easily be misread. Yet members of the public whose families were interned also have something to contribute to those records, as Franca Iacovetta and Roberto Perin claim. ${ }^{7}$ The implications of not engaging with the second generation's reading of their families' official records are clear. Given the age of this generation, it is timely to explore the effects of an encounter with the archives to gain a fuller understanding of internees' life stories. This approach has potential to be carried forward on a larger scale through collaborative projects between institutions and descendants to digitize various types of sources, including archival files, filmed oral testimony, and images.

\section{Contesting official internment records}

In 1942 Sam Ragonesi was 5 years old when his father, Salvatore Ragonesi (1904-1994), was interned. The events of that period left an indelible mark on Sam, not least because his father went into hiding, with an uncle, before the master warrant for their arrests could be enacted, and successfully evaded police for three months. ${ }^{8}$ Obtaining his father's records sixty-three years later with the help of his own son, ${ }^{9}$ Sam discovered an official history that contrasted starkly with what had been related with some pride and amusement in the family for years. While family correspondence has been lost, Salvatore and other family members talked freely about the events around his internment, reinforcing family lore and shaping memories during Sam's upbringing and adulthood. Sam's strongest memories revolve around Salvatore's 'escaping' capture and the family jokes at the expense of local police. The irreverence and flouting of authority in the family's narratives are akin to the spirit of larrikin tales. ${ }^{10}$

However, Salvatore's official documents tell a different story, and one with large gaps, prompting a series of questions about what he and his family went through: Why did Salvatore evade arrest and how did he manage to stay in hiding for three months? What did he believe to be the reason he was interned?

\footnotetext{
${ }^{7}$ Franca Iacovetta and Roberto Perin, "Italians in Wartime Internment" in Iacovetta et al., eds, Enemies Within, p.14.

${ }^{8}$ Evading arrest for internment was very rare. In the fortnightly "Aliens" notices of the Queensland Police Gazette in 1942, which covered news across Australia, only four people were reported as in hiding and "wanted", all of them Queensland Italians, including Salvatore Ragonesi. Most notices concerned people simply failing to inform police of a change of address. There were also three Germans who had escaped from an internment camp. ${ }^{9}$ Sam and his son, Sam junior, requested copies of Salvatore's official internment records on 19 May 2005, which the National Archives of Australia (NAA) sent them on 24 June 2005. Sam discussed these records with the other two authors on various occasions, especially as further documents were gradually obtained. These conversations were recorded between 23 June 2013 and 7 January 2017.

10 In Australia the term 'larrikin' emerged in the 1870s to describe men of low socio-economic status, and often violent ones, only gaining positive connotations from around 1915. Melissa Bellanta, Larrikins: A History (St Lucia, 2012).
} 
What happened to his wife and son during his absence, while in hiding and then over his two years and four months of internment and conscription to the Civil Aliens Corps (CAC)? Similar questions have been asked before in relation to individuals' stories of internment, ${ }^{11}$ but Sam's account also covers the more recent past and questions arising from access to his father's internment documents. How did Sam interpret his father's attempts to naturalize and the authorities' rejections? What effect did seeing his father's "wanted" notice, published in the Queensland Police Gazette, have on him? How did he react to the transcripts of his father's appeal hearing? Overall, how does the official public record challenge the narrative that had developed in Sam's mind from his own experience - his memories and the storytelling within his family over the years?

This discussion sits within the wider discourse of the role of life stories in informing collective accounts of the past. Recent studies demonstrate the significance of the ways in which oral testimonies speak to the silences inherent in authoritative official files. ${ }^{12}$ Francis Blouin Jr and William Rosenberg question "the role of archives when an individual memory challenges prevailing collective ones, when local memories contest the 'great story,' when history becomes histories and the past becomes pasts" ${ }^{13}$ Also at issue here is the effect of consulting documents produced by law-enforcement agents, which, as Tony Kushner highlights, may "criminalize rather than [...] humanize." 14 Of course, oral histories are also problematic. However, it is generally accepted that the selective nature of remembering and forgetting, evident in oral family and community histories - and shaped from "existing myths, images and ideologies", as Ruth Finnegan argues ${ }^{15}$ - does not diminish their importance for informing knowledge of the past. Indeed, historians exploring new possibilities by combining archival evidence and oral testimony have begun to reconceptualize collaborations as "sharing authority". ${ }^{16}$ As

\footnotetext{
11 See Michal Bosworth, "Fremantle Interned: The Italian Experience" in Bosworth and Ugolini, eds, War, pp.86-87.

12 See: David Zeitlyn, "Anthropology in and of the Archives: Possible Futures and Contingent Pasts. Archives as Anthropological Surrogates", Annual Review of Anthropology, Vol. 41 (2012), pp.461-480; Antoinette Burton, ed., Archive Stories: Facts, Fictions, and the Writing of History (Durham, 2005); Max Paul Friedman, "Private Memory, Public Records, and Contested Terrain: Weighing Oral Testimony in the Deportation of Germans from Latin America during World War II", The Oral History Review, Vol. 27, 1 (2000), pp.1-16; Alistair Thomson, "Four Paradigm Transformations in Oral History", The Oral History Review, Vol. 34, 1 (2007), pp.49-70.

13 Francis X. Blouin Jr and William G. Rosenberg, eds, Archives, Documentation, and Institutions of Social Memory: Essays from the Sawyer Seminar (Ann Arbor, 2010), p.256. 14 Tony Kushner, "Alienated Memories: Migrants and the Silences of the Archive", in Joan Tumblety, ed., Memory and History: Understanding Memory as a Source and Subject (Abingdon, 2013), p.189.

15 Ruth Finnegan, "Family Myths, Memories and Interviewing", in Robert Perks and Alistair Thomson, eds, The Oral History Reader, 2nd ed. (London, [1994] 2006), p.180.

16 Michael Frisch, "Sharing Authority: Oral History and the Collaborative Process", The Oral History Review, Vol. 30, 1 (2003), p.113; Steven High, "Telling Stories: A Reflection on Oral History and New Media", Oral History, Vol. 38, 1 (2010), pp.102-103.
} 
archivist Chris Hurley puts it: "If these are your records, where are your stories?". ${ }^{17}$

To date a small number of Italian internees, family members, and communities have made invaluable contributions. While most of the interned adults have now died, their children - some also having been interned - and other relatives still recall and have strong feelings about the experience. ${ }^{18}$ In addition, academic and family historians have facilitated their memories and voices. ${ }^{19}$ Not surprisingly, very few autobiographical or descendants' accounts have drawn on official records. Although many scholars and ex-internees and descendants have tackled internment policy in general, 20 descendants of internees seem to be reluctant to engage with and contest the records. Indeed, those who have consulted the archives have tended to do so to obtain factual information rather than to question how their family members are represented. The decision of the Tully District Italian Pioneers Committee to self-censor memories of internment in their 2007 publication, and to include only a summary mention of events, provides some insight into this reluctance to explore archival records in any depth. Tully's Italian Australians all had someone from their family or close circle of friends interned. However, to tell their individual internment stories in the book would have confronted many of the descendants of those implicated in instigating the internments, who still lived in the town. ${ }^{21}$

17 Chris Hurley, "Parallel Provenance: (1) What, If Anything, Is Archival Description?", Archives and Manuscripts, Vol. 33, 1 (2005), pp.111-112.

18 See: Bonutto, A Migrant's Life; Caroline Alcorso and Claudio Alcorso, "Italians in Australia during World War II", in Stephen Castles, Caroline Alcorso, Gaetano Rando and Ellie Vasta, eds, Australia's Italians: Culture and Community in a Changing Society (North Sydney, 1992), pp.18-34; Claudio Alcorso, The Wind You Say. An Italian in Australia (Pymble, 1993); Peter Dalseno, Sugar, Tears \& Eyeties (Brisbane, 1994); Ian Bonaccorso, Addio Italia: Hello Australia: Stanthorpe Italian Pioneers (Brisbane, 2008); Francesco Arcidiacono and Morwenna Arcidiacono, eds, Echoes of Italian Voices: Family Histories from Queensland's Granite Belt (Stanthorpe, 2009); Carl Saffigna, Half a World Away... Italians in the Redlands (Amity Point, 2014); Spizzica, ed., Hidden Lives.

19 See: Giuseppe Z. in Morag Loh, ed., With Courage in their Cases: The Experiences of Thirty-five Italian Immigrant Workers and their Families in Australia, 3rd ed. (Melbourne, 1980); Josephine Cabassi, Clementina Pruiti, Angela Wayne, née Travia, and Luigi Camporeale in Richard Bosworth, ed., "Oral Histories of Internment," in Bosworth and Ugolini, eds, War, pp.105116; Vilma Watkins, Pukunja (Hurstville, 1999); Toni Koller in Tony De Bolfo, In Search of Kings (Pymble, 2002); Ada De Munari Choat, Alf Martinuzzi and Ilma Martinuzzi O’Brien, eds, Italian Pioneers in the Innisfail District (Brisbane, 2003); Gaetano Rando, "Tales of Internment: The Story of Andrea La Macchia", in Cate Elkner, Ilma Martinuzzi O'Brien, Gaetano Rando and Anthony Cappello, eds, Enemy Aliens, pp.35-54; Arcidiacono and Arcidiacono, Echoes; Zoë Boccabella, Joe's Fruit Shop and Milk Bar (Sydney, 2015); Spizzica, ed., Hidden Lives.

20 See footnotes $3,18,19$.

21 Personal communication from Vince Silvestro to author 1, 16 March 2018 and 3 April 2018; Tully District Italian Pioneers Committee, Hearts Full of Hope: A Collection of Stories, Photos and Memories of the Italian Pioneers of the Tully District (Tully, 2007). 
The imbalanced perspective of official records has already prompted some historians of internment to combine archival analysis with interviews. ${ }^{22}$ Gianfranco Cresciani states that this offered a more "comprehensive picture". ${ }^{23}$ Michal Bosworth found that "oral evidence confuse[d] [the] neatness" of the divisions between Fascists and anti-Fascists conveyed in official records. ${ }^{24}$ And Kay Saunders notes the "disjuncture" between archival and oral sources: "what is so clearly evident is that the stories of those incarcerated and the families they left behind bear no resemblance to documents found in military security dossiers". 25

Our article seeks to provide some foundation for going one step further in the emerging conversation about bringing private narratives into the archives, ${ }^{26}$ through the analysis of one case study, which suggests the potential benefits that collaborative digitization projects between institutions and individuals might bring to the broader public. Combining official wartime records, ${ }^{27}$ newspaper reports and Sam's oral testimony, we piece together an account of key events in Salvatore's life at that critical time in Australia's history. After outlining Salvatore's background and migration, and events leading up to and following his internment, by interweaving Sam's recollections with data from Salvatore's official documents, we focus on Sam's reactions to reading those records. Sam's words are italicized throughout to highlight the intertwining of his father's life story with his own.

\footnotetext{
22 See: Gianfranco Cresciani, Fascism, Anti-Fascism and Italians in Australia, 1922-1945 (Canberra, 1980); Kay Saunders, “'Taken away to be shot?': The Process of Incarceration in Australia in World War II", in Saunders and Daniels, eds, Alien Justice, pp.152-167; Bosworth "Fremantle Interned"; Bevege Behind Barbed Wire, pp.xviii-xx; Saunders, "'Discovering'"; Kay Saunders, "A Difficult Reconciliation: Civil Liberties and Internment Policy in Australia during World War Two", in Saunders and Daniels, eds, Alien Justice, pp.114-137; Wendy Ugolini, Experiencing War As the "Enemy Other": Italian Scottish Experience in World War II (Manchester, 2011); Spizzica, ed., Hidden Lives, pp.258-294.

23 Cresciani, Fascism, p.251.

24 Bosworth, "Fremantle Interned", p.82.

25 Saunders, "'Discovering'", pp.9-10.

26 On the historiography and debates about bringing oral histories into archives and libraries, and the central role of oral testimony for enriching official records, see: Ellen D. Swain, "Oral History in the Archives: Its documentary Role in the Twenty-First Century", in Perks and Thomson, eds, The Oral History Reader, pp.343-361. The far-reaching potential of this approach is demonstrated through digital storytelling in the Montreal Life Stories project: High, "Telling Stories", pp.101-112. On how the digital storytelling format "enables rich, multilayered and multimedia history that combines different types of sources (images, objects, music, sound effects, interviews and documents), each of which carry distinctive historical meanings", see: Johnny Bell, Rebecca Carland, Peg Frazer and Alistair Thomson, "'History Is a Conversation': Teaching Student Historians through Making Digital Histories", History Australia, Vol. 13, 3 (2016), p.430.

27 Australian World War II internment files tend to hold details about pre-internment investigations (including personal migration documents and applications for naturalization), capture and internment, and the Alien Tribunal's appeal hearings. They also include the Australian Military Forces Service and Casualty forms (AMF), which track prisoners' movements through camps and conscription to the CAC.
} 


\section{Social and cultural layers of Salvatore's internment story}

Born in the village of Castiglione near Catania, Sicily, in 1904, Salvatore worked as a farm labourer before migrating to Queensland at the age of 21 to work in the sugar industry, sponsored by his brother-in-law, Giuseppe Grasso. ${ }^{28} \mathrm{Dad}$ spoke only Sicilian ... he was illiterate, he had little schooling ... He eventually learned to read and write some Italian after migrating... He could understand and speak only basic English. Salvatore arrived in Brisbane on the Re d'Italia on 7 June 1925. ${ }^{29}$

The 1920s and 1930s were a time of growing anti-Italian sentiment in Queensland, linked to fearful reactions to the increasing migration of Southern Italians, economic anxieties, crimes of the Black Hand ${ }^{30}$ and, after 1935, some activity of fascist cells (fasci). ${ }^{31}$ Notably, Salvatore disembarked within five days of the release of a Royal Commission report on the social and economic impact of non-British migrants in North Queensland. Known as the Ferry Report, it specifically targeted Southern Italians - especially Sicilians - as well as Greeks, Albanians and Maltese people, as a "hopelessly inferior type" of migrant. ${ }^{32}$ Commissioner T.A. Ferry wrote that Southern Italians brought an insular culture, inconsistent with Australian workers' values; they were "more inclined to form groups and less likely to be assimilated" (than British migrants), and were buying up farms and forming cutter gangs that "displaced" Anglo-Australians in the sugar industry. ${ }^{33}$ Such views had also manifested in the press. For example, when the Re d'Italia docked in Melbourne, The Brisbane Courier described the immigrants on board as of inferior quality and "distrustful":

255 were travelling to the sugar fields of North Queensland. Nearly all were men, and their general standard did not appear to be up to that of some of the former contingents of Italians. ... Photographers were not allowed on board the ship, and were forbidden to take photographs of the third class passengers. The migrants appeared distrustful. ${ }^{34}$

\footnotetext{
28 Alien Registration Application, 4 October 1939, and "Aliens Tribunal", 9 October 1942, NAA, BP242/1, Q16274.

${ }^{29}$ Report, AMF, 14 July 1942, ibid.

30 See: William Douglass, From Italy to Ingham: Italians in North Queensland (St Lucia, 1995), pp.220-234.

31 See David Brown, “'Gathered around the Sign of the Littorio': The Italo-Abyssinia Conflict and Its Impact on Italian Fascism in Queensland, 1935-1939“, Spunti e Ricerche, Vol. 24 ([2009] 2011), pp.56-66.

32 Commissioner T.A. Ferry and Queensland Alien Immigration Commission, Report of the Royal Commission Appointed to Inquire into and Report on the Social and Economic Effect of Increase in Number of Aliens in North Queensland (Brisbane, 1925), p.17.

33 Ibid., pp.16-22.

34 "For Queensland. Big Contingent on Re d'Italia", The Brisbane Courier, 26 May 1925, p.10.
} 
Salvatore headed directly for North Queensland, where he worked as a cane cutter and farm labourer in Daradgee, near Innisfail, over the next few years. ${ }^{35}$ In 1930 he applied for naturalization, but the decision was: "Refused because he cannot speak English". ${ }^{36}$ Two years later he travelled to Italy to visit his parents, staying for five months before returning to Queensland on the Otranto. On this voyage he chaperoned the three children of a co-worker, Filippo Testa (from Calatabiano, Catania), who were coming to join their father in Queensland: Concetta, aged 18, Antonio (Tony), aged 16, and Giuseppe (Joe), aged 13. ${ }^{37}$ From 1933 Salvatore cut sugar cane in Mossman, Moresby, Boogan and Daradgee. He married Concetta Testa in Innisfail on 2 January 1935, although the police records mistakenly give the year as $1925 .{ }^{38}$

By September 1935 Salvatore was caught up in the notorious cane cutters' strike. Strikers demanded that the cane be burnt before harvesting, to prevent Weil's disease, which was spread by rats and caused the horrific deaths of many cutters. ${ }^{39}$ At a certain point during the strike, the Australian Workers' Union (AWU) instructed its members back to work. C.G. Fallon, the AWU State Secretary, articulated the Union's position, noting also that this was to be "translated into Italian ... and ... circulated among the foreigners". 40 The strikers passed a motion in response, deploring the use of scabs, "condemn[ing] the strike-breaking attitude of union officials", and expressing determination to "fight to the finish". ${ }^{41}$ Salvatore was among the few 'scabs' (as Sam also describes them) who obeyed the Union's instructions. Such loyalty was later to enable Salvatore to appeal to Mr Fallon for help during his internment.

In 1939 Salvatore again attempted to naturalize. This time, the situation seemed more promising, with a number of community members vouching for him as "of good character and ... a good, honest, reliable worker", described as "well-known ... and ... spoken well of by all who have come into contact with him". ${ }^{42}$ He explained in his naturalization interview that he was in the process of "purchasing a farm property with his uncle and cousin [sic], Filipo [sic] and Antonio Testa, of Garradunga ... wish[ing] to bring up his family on this property so that they [could] enjoy the rights and privileges of [a] British subject". ${ }^{43}$ However, the assessment of Salvatore's application became a lengthy and convoluted process. As the police investigators wrongly spelled some Italian employers' names, there was confusion about whom he had

\footnotetext{
35 Report, Naturalization Application, 5 April 1939, NAA, BP242/1, Q16274.

36 Transcript, "Aliens Tribunal", 9 October 1942, ibid.

37 Atto di Chiamata, 7 January 1932, ibid.

38 Queensland Marriage Certificate, 2 January 1935, Queensland Births, Deaths and

Marriages, no. 1935/185; Report, Cairns Police District, 5 April 1939, NAA, A367, C47703.

39 Diane Menghetti, The Red North: The Popular Front in North Queensland (Townsville, 1981), pp.27-32.

40 "200 Farmers Ready to Cut Cane", The Courier Mail, 9 September 1935, p.11.

41 The Townsville Daily Bulletin, 9 September 1935, p.4.

42 Report, Cairns Police District, 6 March 1939, NAA, BP242/1, Q16274.

43 Report, Naturalization Application, 5 April 1939, ibid. As Sam noted, Filippo and Antonio Testa were Salvatore's father-in-law and brother-in-law, respectively.
} 
worked for, and two Italian employers in Mossman failed to confirm that they had employed him when shown his passport photograph. ${ }^{44}$ The Criminal Investigation Branch (CIB) of Queensland Police confirmed Salvatore had no "criminal history", but his application was rejected again and his passport unlawfully - never returned. ${ }^{45}$ Newspaper reports linking Sicilians and Calabrians to suspected "Black Hand" organized crime in North Queensland between 1932 and 1939 contributed to a climate of suspicion towards Italians, ${ }^{46}$ and may have influenced the processing of their naturalization applications. Europe's developing conflict would have accentuated officials' reservations about Italians, especially after Mussolini invaded Abyssinia in 1935. ${ }^{47}$ However, the decision on Salvatore's application again cited poor English as the reason for rejection. ${ }^{48}$

Being unnaturalized, Salvatore was required to register as an "Alien of Italian Nationality" in accordance with the National Security Act of 1939, which he did in Innisfail on 4 October that year. ${ }^{49}$ Arrests of Italian migrants began after Mussolini declared war on Britain on 10 June 1940, and were stepped up after the fall of Singapore on 15 February 1942, which produced widespread fears of a Japanese invasion. ${ }^{50}$ Many government officials and members of the public were convinced that Italians posed a threat to North Queensland's security, being "suspected of Axis sympathies", and this precipitated the mass arrests of "enemy aliens". ${ }^{51}$ The Fascist regime's propagandistic claims about transforming "innocent peasants and labourers" overseas into devoted militants further fed concerns. ${ }^{52}$ Acknowledging the influence of public opinion and the fear of a Japanese invasion as increasing the pressure on Italians in North Queensland, Ilma Martinuzzi O'Brien states that some protests against Italians in 1940 also reflected "a high level of economic envy", motivated by ethnic "hostility". ${ }^{53}$ Such sentiments continued around the time mass warrants were issued in 1942 and indeed throughout and after the War, with plans made

\footnotetext{
44 Report, Cairns Police District, 17 April 1939, ibid.

45 Letter, CIB, Queensland Police, Brisbane, 9 May 1939, ibid. According to the Alien Registration 1927 Shipboard Regulations, Salvatore was entitled to keep his passport: Letter, R.F.B. Wake to Commissioner of Police, Brisbane, 6 March 1939, ibid.

46 Douglass, From Italy, pp.226-234.

47 Roslyn Pesman Cooper, "'We Want a Mussolini': Views of Fascist Italy in Australia”, Australian Journal of Politics and History, Vol. 39, 3 (1993), pp.356-357.

48 Report, Cairns Police District, 5 April 1939, NAA A367, C47703.

49 Report, Cairns Police District, 22 March 1945, ibid.

50 Subsequent attacks on Darwin also alarmed the government. Paul Hasluck, The Government and the People, 1942-1945. Volume II (Canberra, 1970), pp.70-72.

51 See: Ilma Martinuzzi O’Brien, “The Internment of Australian Born and Naturalised British Subjects of Italian Origin", in Bosworth and Ugolini, eds, War, pp.99-100, 102; Douglass, From Italy, pp.239-241; Bevege, Behind Barbed Wire, p.58.

52 Cresciani, Fascism, p.86.

53 Martinuzzi O’Brien, “Italians in Ingham and Innisfail”, pp.82-83, 87.
} 
to disperse Italians' farms to ex-servicemen. ${ }^{54}$ Yet economic interests were generally entangled with cultural and ideological (loyalty) factors. ${ }^{55}$ Both the authorities and general public tended to believe that, in the event of invasion, not only "enemy aliens" but also naturalized migrants would switch alliances to the invader because their attachment to their farms would prevail over loyalty to the Australian government. ${ }^{56}$ As Margaret Bevege states: "Official action was to keep in step with [...] public sentiment". ${ }^{57}$

Although internment camps were quickly created to counteract sabotage, calm the public outcry, and confine some of the Allies' prisoners of war, 58 the nation's infrastructure, personnel and bureaucracy were largely unprepared, which meant mistakes were made about individuals' identities and in personal details in their records. ${ }^{59}$ This became apparent in documents from local police investigations instituted after an amendment to the National Security Act empowered "all constables and Commonwealth Officers" to arrest "any enemy alien". ${ }^{60}$ Salvatore's case provides several examples.

Two Cairns Police reports of February 1942 into Salvatore's "sentiments, activities, associates[, and] loyalty" reflect the heightened concern for national security:

This man has only got a poor knowledge of the English language, his principal associates are Sicilians, he only comes to Innisfail occasionally, when he does he can be found associating with his Countrymen. I have made thorough inquiries regarding this man, very little is known about him but it is generally believed by those who do know him that his sentiments are pro-Italian. From the result of my inquiries I am of the opinion that this man has anti British Sentiments, on account of that, and being unnaturalized I am of the opinion that he is a fit subject of internment. ${ }^{61}$

and:

There is no definite evidence available here as to him being a Fascist or disloyal, but he is suspected of having Fascist tendencies. ... His main associates whilst here were Sicilians. This man is a reputed Fascist and was an associate of reputed Fascists whilst resident here, and in view of the

\footnotetext{
54 Ilma Martinuzzi O’Brien, "Citizenship, Rights and Emergency Powers in Second World War Australia", Australian Journal of Politics and History, Vol. 53, 2 (2007), p.212; Douglass, From Italy, pp.240-241, 248-249, 254-255.

55 See Martinuzzi O'Brien, "Citizenship", pp.210-211.

56 Bevege, Behind Barbed Wire, pp.xvii, 53, 159.

57 Ibid, p.53.

58 Neumann, In the Interest, p.7.

${ }^{59}$ Don Dignan, "The Internment of Italians in Queensland", in Bosworth and Ugolini, eds, War, pp.64-65; Martinuzzi O'Brien, "The Internment of Australian Born", p.95; Martinuzzi O'Brien in Sardi, The Internment Diaries, p.6.

60 Cf. Detention Order, 26 March 1942, NAA, BP242/1, Q16274.

${ }^{61}$ Report, Cairns Police District, 24 February 1942, ibid.
} 
present international situation I am of the opinion that he should be interned. 62

Within a month, on 26 March 1942, Brigadier Alexander Moore Forbes of the Northern Command Section of the Australian Internment Corps issued a master warrant for several arrests, including Salvatore's, ${ }^{63}$ as part of what Martinuzzi O'Brien describes as North Queensland's "great round-up". ${ }^{64}$

\section{Family memories of Salvatore's internment story}

Soon after the issuing of the master warrant, Salvatore and his brother-in-law, Giuseppe Testa, went missing. According to Cairns Police Constable Gorey:

[Salvatore's] arrest was first attempted on the 11-4-42 but when his home was visited by the Police on that date it was discovered that he had disappeared. A continuous search was made for [him] and his relations questioned by the Police, but they denied all knowledge of [his] whereabouts. 65

Sam explains that, among other local Italians, Salvatore's father-in-law, Filippo Testa, had already been arrested, so Salvatore and Giuseppe assumed the police would soon come for them too. Sam's account of why his father and uncle went into hiding suggests they thought it would only be necessary to lie low for a short time, until the authorities forgot all about it, so they could resume running the farm:

Because we didn't want to lose ... our property [at Garradunga], to the extent that we could look after it you know, Dad and my uncle went into hiding. ... they said "at least we can turn around and we might be able to work the farm".

Salvatore and Giuseppe used a hideout that family members had built earlier, fearing they would all need to hide in the event of a Japanese invasion, in order to protect the women from Japanese soldiers. The hideout was near Boogan, on the farm of a cousin, Rosaria 'Rose' (née Sciacca) Castorina, whom Sam describes as: My godmother, who used to be the front-runner.

Uncle [Giuseppe Castorina] had built this hut ... dug in underneath on the banks of the Johnstone river; it was a cave ... It was well done, it was all soil, you know, on the side, but it could've housed probably about 12, 14 of us... so we could get away from the Japs.

\footnotetext{
62 Report, Cairns Police District, 27 February 1942, ibid.

63 Letter, Deputy Director of Security, Queensland, to Director General of Security, Canberra, 3 December 1942, NAA, A367, C47703.

64 Martinuzzi O'Brien in Sardi, The Internment Diaries, p.1.

65 Report, Cairns Police District, 22 March 1945, NAA, A367, C47703.
} 
Sam explains that Salvatore and Giuseppe managed to avoid being captured because the hut was particularly well camouflaged:

And the beauty was that when the police used to come and look for my father, they used to sit on top of the hut!... There was a bloody steep drop ... you know, and that was the least place they'd look, and that's where they were hiding... They had a galvanized roof... and all soil and everything put on the top of it, but it was solidly built and the police would often stand on there and talk: "those bastards must be somewhere around here!", they'd say.

The life Sam describes while his father was in hiding, and subsequently interned, was one of considerable isolation. The family had very little contact with townspeople, or indeed anyone beyond family.

And they were in hiding for ... about a couple of months ... and from there on, just... life went on as it was. Me and my auntie [Tony's wife, Agata (née Pennisi) Testa] and my mum were left by ourselves on this [Garradunga] property in North Queensland and we had a friend that used to help us out on the property and that was about it.

Sam spoke only Sicilian at that time.

You see I never went to school. So you had no friends. Nobody used to come and look you up. We just lived in this beautiful big Queenslander all by ourselves ... So you know you're sort of isolated from the outside world. ... They closed the schools too ... in North Queensland. Then I started school [in 1945] when I was about 8 years of age. And I couldn't speak English ...

Sam does not remember experiencing hostility from the non-Italian local people when he was a child, just a sense of distance. On the rare occasions in which they went to town, he recalls:

They used to just look at you, you know. Most people in Innisfail in the streets in those days knew that you were a foreigner and you couldn't speak good English, so you were forgiven, more or less.

Although Sam labels his family and himself here as foreigners, he, like his godmother Rose, was born in Australia, his uncle Tony had been naturalized before the War, his father had been in Australia for seventeen years when interned, and all the adults were contributing to Queensland's economy.

Although Sam did not perceive anti-Italian sentiment in general as a child, he recounts that his family attributed Salvatore's and Giuseppe's internment to an Anglo-Australian neighbour who reported them as Fascists:

One of our neighbours was [anti-Italian], that's ... why they got interned ... because they dobbed 'em in as Fascists ... My old man and my uncle was the only ones interned on that road. These people were dirty on 'em because the farm wasn't 
worth two bob but the uncle and the whole four of 'em got off their arses, started working hard, and they started to thrive and grow good sugar cane, so they dobbed 'em in. And of course ... up there they were promised that, if the Ities got ... run off their land, half those farms would go to the ex-servicemen who came back from the war. 66

Salvatore's archival records do not contain the names of accusers, nor any evidence of censored sections, but Sam's point is nevertheless plausible, given internal police processes "to protect the confidentiality of the informer". ${ }^{67}$ Accusations about associating with so-called Fascists were enough to intern many. ${ }^{68}$

Sam recalls the explanation his mother and aunt had given him for his father's hiding and internment:

Because we had gone into bed with the Japs. So that was the rumour around in those days, that the Italians, the Japs and Germans were bad people ... We were the enemy. ... We were like outcasts in society. ... You just took it for granted that the Italians and the Germans were bad people. They got interned and taken away and that was it. Part and parcel of the system.

Even when his father returned home after his internment, the perception that he was an outcast was still strong:

It was [difficult for Dad] because people would say "bloody dagoes; they're still hanging around". They still had that sinister feeling towards them. Even though the Italian government had turncoated. ... Even the soldiers who came home, when the Italians had become part of the Allies, still referred to the older generation, especially those who were interned, as outcasts.

While Salvatore was in hiding, Sam and his mother would occasionally take a 3 mile walk from their farm to Garradunga station, a train trip to Boogan, and another couple of miles' walk to the Castorina farm to see him: We'd go to my godmother's place and ... he'd come out at night time... And they'd all get together and have a chin wag. Sam remembers feeling very frightened one day on the Castorina farm with his mother, aunt and godmother, when they were accosted by several police. In Sam's reenactment of this, Rose stood up to them:

Godmother: Are you accusing me?

Police: $\quad$ Course we are; you know where they're hidden.

Godmother: Well, you come here all the time. Have you found 'em?

Police: $\quad$ No but we know you're harbouring 'em.

Godmother: Well go ahead and search my house. Do what you like!

\footnotetext{
${ }^{66}$ Notably, Italians' economic success contributed to ex-servicemen's interest in their properties: Dignan, "The Internment of Italians", pp.70-71.

67 Martinuzzi O'Brien, “The Internment of Australian Born”, p.103.

68 Bosworth, "Fremantle Interned", p.84.
} 
Such brazenness came through in Sam's narration of other episodes too. For example, there was the story of a policeman searching his uncle Tony's barn for the missing men and getting his hand caught in a rat trap which Tony had deliberately neglected to warn him about. The policeman consequently threatened Tony with internment (which Tony had unrealistically hoped to be protected from by his naturalized status), and this occurred on 4 May 1942. ${ }^{69}$ Similarly, Sam spoke of a woman who turned herself and her mother in after her husband was interned because she could not face running the farm beside a crocodile-infested river alone: She started abusing the cops. ... "You so-and-so! I'm a Fascist supporter! ... You bastards interned my husband, you can intern me too!" ... She says [later] "at least we weren't left there among the crocodiles!". While they evidently held little fear of local police, Salvatore's family members were afraid of not only a Japanese invasion but also US soldiers travelling nearby:

$[W]$ e used to go to bed early and lock ourselves in the bedroom.... We used to be scared at night, the women in particular. ... Because about two kilometres away was the main highway that the Yanks used to go through ... and they thought the Yanks might ... come up to the house.

Archival documents state that Salvatore and Giuseppe were "intercepted and arrested at the home of [Salvatore's] sister-in-law Mrs Carmela Testa, at Garradunga", and taken to Innisfail Police Station, on 1 July $1942 .{ }^{70}$ But Sam states that his father and uncle actually gave themselves up because the police had threatened to arrest their wives and children; that Salvatore and Giuseppe went to a solicitor in town and the process was initiated from the solicitor's office. ${ }^{71}$ Constable Gorey later recorded what Salvatore "admitted" to him about his "disappearance":

Questioned as to his reasons for attempting to evade arrest and to his whereabouts at that time, he informed me that he was afraid to leave his wife and family without protection and that when he heard the Police were looking for him he had ran [sic] away into the scrub near his home. Continuing he stated that he would stay in the scrub all day and for the greater part of the night and would return home in the early hours of the morning ... [W] hen it was necessary for him to remain in hiding for two or three days at a time, food was brought to him by his wife and other members of the family. ${ }^{72}$

This explanation no doubt reflects Salvatore's concern to keep the hideout at Boogan secret and avoid implicating his Castorina relatives. Yet it is also

\footnotetext{
${ }^{69}$ AMF, NAA, MP1103/1, Q30275.

70 Report, Cairns Police District, 22 March 1945, NAA, A367, C47703. Internment occurred on 20 July 1942: AMF, NAA, MP1103/1, Q8724.

71 While no correspondence exists in Salvatore's records to support this, there is evidence that Concetta later engaged Mighell Lee-Bryce \& Vandeleur Solicitors in Innisfail to apply to have her husband released from work on the Transcontinental Railway: NAA, A367, C47703. 72 Report, Cairns Police District, 22 March 1945, ibid.
} 
consistent with his initial plan of returning to the farm to maintain it, which Salvatore explained to Sam in later years.

\section{Salvatore's perspective}

Insights into Salvatore's views emerge from the documents pertaining to his appeal hearing, held in Brisbane on 9 October 1942, where he pleaded: "I have always been loyal to this country and respectfully ask that release may be granted". ${ }^{73}$ Giuseppe, with whom he had been hiding, acted as interpreter. The Chairman of the Aliens Tribunal outlined four "charges" against Salvatore: "he has been here since 1925 and ... is not naturalised"; "he is an enemy alien of military age and has a poor knowledge of the English language"; "he is ProItalian in sympathies. He supports the Italian cause"; and "he is reported to be a Fascist and is an associate - that is, he is a friend - of Fascists or reputed Fascists" . ${ }^{74}$ Salvatore denied these charges, as Giuseppe conveyed:

He says that in 1930 he made application to be naturalised and it was refused because he cannot speak English. ... He tried to learn but cannot read it. They have not got the time. They have been working all the time on their job in the North and he is very tired when he reaches home. ... He says that he has been very many years in this country and he likes this country. ... No [He is not a friend of Fascists or reputed Fascists].

and later:

He says he wants to know what you put him in the internment camp for when he wants to defend Australia now there is a war. He says he does not like to stay in the barb-wire fence. He likes to work... He does not like to stay in the internment camp. He ... defend all the time Australia because he has got a son here.

The transcript brought to Sam's attention an element of his father's story of which he had been completely unaware: the support Salvatore had obtained from powerful people. During the hearing, Salvatore drew the Tribunal's attention to the fact that he had been one of the twenty-eight men to break the cane cutters' strike in 1935 and that he was expecting a letter from the AWU State Secretary, C.G. Fallon, to support his appeal. ${ }^{75}$

The wording of Salvatore's letter seeking Mr Fallon's assistance frames his request in terms of loyalty and reciprocal obligation, reminiscent of Sicilian patron-client relationships: "as I have always been loyal to the A.W.U. and to you, I beg you to do all you can to have me released" and "As I have nobody in Australia to look after my interests, please help me, and I will be forever very

\footnotetext{
${ }^{73}$ Letter, Salvatore Ragonesi to Commandant of Gaythorne Internment Camp, 15 September 1942, ibid.

74 Transcript, “Aliens Tribunal”, 9 October 1942, NAA, BP242/1, Q16274.

75 Ibid.
} 
obliged". ${ }^{76} \mathrm{He}$ also expressed his desire "to join my family and continue to work" and affirmed his "loyalty to the British Empire and Australia". C.G. Fallon in turn appealed directly to the Minister for External Affairs and Attorney General in the War Cabinet, Dr H.V. Evatt. In his letter he vouched for Salvatore personally, through such wording as "knowing him as I do", and described him as "a typical 'Man of the Hoe'. Does not know much about politics or Unionism", but "passionately attached to his family and the soil, and grateful for the fact that he is in Australia". This was a man who had "no sympathy for Mussolini or Fascism" and was "not dangerous in any way". C.G. Fallon asked the Minister to "be good enough to personally peruse the papers associated with his Appeal". ${ }^{77}$ Acting on behalf of Minister Evatt, following "representations ... received", the Commonwealth Director General of Security wrote to the Deputy Director of Security for Queensland - requesting information on the outcome of Salvatore's hearing - and to C.G. Fallon. ${ }^{78}$

The support of C.G. Fallon (and possibly the Minister) for Salvatore arrived too late; the Tribunal had already decided he was still a risk to the country. ${ }^{79}$ After four months at Gaythorne Internment Camp (from 14 July 1942) he was transferred to Loveday Internment Camp (18 November 1942). ${ }^{80}$

\section{Release and naturalization}

Salvatore's detainment was eventually revoked on 15 June 1943, three months before Italy's surrender, and he was transferred to Wayville Detention Barracks, then released on 22 June 1943 "for employment with" the CAC. ${ }^{81}$ He was set to work on the Transcontinental Railway at 779 Mile Camp, Western Australia. ${ }^{82}$

On 30 November 1943, Concetta engaged a solicitor who wrote to Director General of Security W.B. Simpson, pointing out that Salvatore was not naturalized and therefore not obliged to work for the CAC. Moreover, as Salvatore was "an experienced canecutter and farm labourer", the solicitor continued: "we desire to know whether there is any objection to his returning to Queensland where he could be near his wife and child. We assume that there would be work of national nature that he could do in this State". ${ }^{83}$ The request

\footnotetext{
76 Handwritten and typed letters, Salvatore Ragonesi to C.G. Fallon, 13 October 1942, ibid.

77 Letter, C.G. Fallon to Minister for External Affairs, 22 October 1942, NAA, A367, C47703.

${ }^{78}$ Letter, Director General of Security, Canberra, to Deputy Director of Security, Queensland, 25 November 1942, NAA, BP242/1, Q16274; Letter, Director General of Security, Canberra, to C.G. Fallon, 8 December 1942, NAA, A367, C47703. No evidence of Minister Evatt's personal response exists in Salvatore's files.

79 Report on Hearing recommendation, 2 November 1942, NAA, BP242/1, Q16274.

80 AMF, NAA, MP1103/1, Q8724.

${ }^{81}$ Memo, Deputy Director of Security, Queensland, 15 June 1943, NAA, BP242/1, Q16274; AMF, NAA, MP1103/1, Q8724.

${ }^{82}$ Letter, Deputy Director of Security, South Australia, to Deputy Director of Security, Queensland, and Commonwealth Director General of Security, 22 June 1943, NAA, BP242/1, Q16274.

83 Ibid.
} 
was denied and Salvatore continued to work in Western Australia for seventeen months until he injured his leg. ${ }^{84}$ Described as "very serious", Salvatore's injury entitled him to "unconditional release"; as he "refused" the recommended "urgent surgical treatment", he flew to Townsville on 24 November 1944 because "there was no Security objection to Ragonesi being permitted to travel to his home in Innisfail". 85 South Australian Railways charged him $£ 5 / 17 / 6$ to send his "suitcase, a wooden box and a package". 86

On 23 January 1945 Salvatore attempted naturalization a third time. ${ }^{87}$ This application met with resistance again. Constable Gorey wrote:

As a result of my inquiries in connection with this matter and in view of the fact that he has been a resident of the Country since the year 1925, and has apparently made no attempt to improve his knowledge of the English language I do not consider that he would be a fit and proper person to be granted the Certificate of Naturalization applied for. ${ }^{88}$

It took another fifteen months for Salvatore's English-language skills to be reassessed and naturalization granted, with Constable Long of Mourilyan writing: "the applicant has now improved his knowledge of the English language and can now engage in conversation on ordinary general topics and can carry on his occupation amongst English Speaking people". ${ }^{89}$ But Sam contradicts this report, insisting that his father never sought to learn English, and spoke it very little indeed.

Not long after this, Salvatore left the farm and moved his family to Brisbane. As Sam recalls:

The place had gone to wrack and ruin more or less; there was nobody to run the place for those years ... So Dad packed up and said to the boys, his brother-in-law and father-in-law: "I've had enough; no use me hanging around here." He went cane cutting for about four months and then we packed up and came to Brisbane.

\section{Impact of Sam's encounter with the official records}

Combining the archival documents with Sam's oral testimony produces a fuller version of Salvatore's internment history than that of either source alone: the official records provide no information on how Salvatore and Giuseppe managed to evade capture for three months, while Sam was unaware of union leader Fallon's support and the appeal to Minister Evatt. Yet, this process also

\footnotetext{
${ }^{84}$ Letter, Director General of Security, Canberra, to Mighell Lee-Bryce \& Vandeleur Solicitors, 10 December 1943, ibid; "For Record Purposes" by Security Service, Brisbane, 24 November 1944, ibid.

$85 \mathrm{Ibid}$. Letter, Deputy Director of Security, Queensland, to Commissioner of Police, Brisbane, 28 November 1944, ibid.

86 Ibid.

87 Precis, Naturalization Application, 23 January 1945, ibid.

88 Report, Cairns Police District, 22 March 1945, NAA, A367, C47703.

${ }^{89}$ Report, Cairns Police District, 13 June 1946, NAA, BP242/1, Q16274.
} 
generates another feature of Salvatore's life story: an emotional component that includes not only Sam's beliefs and the family discourse around the internment episode, but also his reaction to reading his father's internment records later an experience that proved very confronting for him.

As we have seen, in Sam's reminiscences of the family talk during his childhood and later, one constant feature is the tone of seemingly lighthearted amusement at Salvatore's (and other family members') resistance against the authorities, portraying larrikin behaviour. The images evoked of policemen appearing quite foolish - as they, for example, scratched their heads in perplexity as to Salvatore's and Giuseppe's whereabouts, while standing atop the hideout, or put a hand into a rat trap while searching Tony's barn, or reacted obediently to a woman's haranguing and self-denunciation as a Fascist illustrate this. Similarly, when asked what his father and uncle talked about when they would reminisce and get together, Sam recalled:

When they used to talk between themselves they'd say "Remember bla bla". ... And they talked about the experiences they had when they were interned in the camps ... Just the funny part about it ... what they had to eat and all that. More in jest, no bad feeling or anything. It was all in jest.

and

Because they were the last two that got rounded up, ... they stuck'em in the watch house. ... Dad and Uncle Joe often laughed about that, that they had to eat stale bread and that, while they were in the watch house. They used to make a joke out of it.

While it might appear that Sam was trying to demonstrate Salvatore's Australianness through such stories, he always stressed that his father did not assimilate well.

The Ragonesis' stories were evidently enjoyed and perhaps embellished: proud tales of outcasts resisting and outsmarting the authorities. The humour in such stories may also have served to distance the memories of internment life. This may explain another recurring feature in Sam's account of the family discourse: an emphasis on acceptance of the situation - however unjust - as simply part of the effects of the War, and nothing personal. Italians were the enemy and therefore bad people; internment reflected this, and was no slight on an individual's character. As Sam put it, when asked if his father had expressed resentment or pain over it:

It never changed the old man. He never hated anybody any more or any less. He said it was part of the system; we got interned; that's what happened and that was part of life. There was no ... grudge in that sense; you just accepted it. ... That was part and parcel of what had happened.

It is perhaps the constant memory of Salvatore's gentle acceptance that made Sam's encounter with the official records challenging. 
Sam reacted to various documents with shock, disbelief and anger. Especially striking was his response to seeing the photographs of his father and uncle, listed as "wanted for internment", in the Queensland Police Gazette (see Figures 1 and 2):

We couldn't believe it! We were taken aback because of the character references that were given to him by all these people [his employers' supportive references in the naturalization applications] and now he was "a wanted man". It's mind boggling! He was a good bloke and noble. Right, he couldn't speak English. Just because of that! I can't believe that his reputation could be tarnished liked that. ... It was just amazing, as if they were bloody criminals.

$<$ Figure removed to ensure author anonymity $>$

Figure 1. Notice, Salvatore Ragonesi, Queensland Police Gazette LXXIX (19) 9 May 1942: p.152. Source: Queensland State Archives.

$<$ Figure removed to ensure author anonymity $>$

Figure 2. Notice, Giuseppe Testa, Queensland Police Gazette LXXIX (20) 16 May 1942: p.159. Source: Queensland State Archives.

Salvatore's archival records do not apply the word 'criminal' to him; it was the association of his father's photograph with the word "wanted", in a police notice, that Sam reacted to. The inaccurate inference he drew - of Salvatore being portrayed as a common criminal - needs to be appreciated in the context of the documents' public accessibility. As Kushner argues, law-enforcement documents, especially if accompanied by photographs, can convey an impression of a criminal type, and suggest public acceptance of the stigmatizing of an ethnic minority ${ }^{90}$. For Sam, seeing Salvatore's photograph was doubly hurtful as it was recognizably in passport style, and it appeared likely that the police had obtained it from the passport the CIB had failed to return upon rejection of Salvatore's second naturalization application. Sam was shocked because it appeared the authorities had taken private property and used it to obtain a mugshot.

Sam also found it extraordinary that the authorities could lock away a person, yet make errors in the particulars of their records. How could the officials date his parents' marriage to when his mother was only 11 years old, for instance? Especially infuriating was the report on his father's and uncle's "capture", describing them as "intercepted ... and arrested at the home of ... Carmela Testa". He wasn't bloody arrested at Carmela Testa's ... There's no such person ... That's bullshit, that's made up. That's fabricated. They gave themselves up, via a solicitor, for an honourable reason: the police had threatened to arrest their wives and children. That official reports could gloss over details about Salvatore's and Giuseppe's decision to safeguard their families, while the

90 See Kushner, “Alienated Memories", pp.182, 189. 
authorities denied these men their liberty and exposed their families to poverty and fearful isolation, made no sense to him at all.

On reading his father's appeal hearing transcript, Sam was again baffled and angry. His father had tried to naturalize twice and failed because of his minimal English, yet the transcript listed as the first allegation for internment the fact that he was "not naturalised" (followed by his being "an enemy alien", having "poor knowledge of the English language", being considered "ProItalian" and "reported to be a Fascist)". Sam's reaction:

Couldn't believe it. ... It was like a one-man court. ... If it was supposed to be justice, how could it? ... This poor man's telling you the truth. You don't believe him. So what bloody good is it? It's irrespective of what he'd say. ... He couldn't get naturalized because he couldn't speak English. But he tried to become a British subject, so you can't hold that against him.

Sam's understandably subjective reading of the transcript, which exacerbated his sense of the injustice enacted on his father, could not be expected to take into account the impersonal nature of the national security procedures. But the elements that confused and angered Sam do match the concerns about the hearing process identified recently by David Henderson: these hearings were not set up to follow "British justice" but were conducted secretly, protected accusers, were dominated by military personnel, and proceeded from an assumption of guilt. ${ }^{91}$

One of the most incomprehensible discrepancies between the Ragonesi family story and the official documents concerned Salvatore being labelled "Fascist". Anger flared repeatedly in Sam's comments as he looked through the documents. Reading from a police report on his father's "sentiments and activities" the more positive description, "Ragonesi is well known here and regarded as a good man and a good worker. There is no definite evidence available here as to him being a Fascist or disloyal", 92 Sam exclaimed: That's right! And yet they classed him as a Fascist. Reflecting, later, on how he has come to see the internment and naturalization processes overall, Sam concluded:

I believe that most of them were biased against these poor people. Although I do feel hurt that Dad was interned, I feel that 90 per cent of the others would have been in the same predicament. There would have been some Fascist supporters ... but most of these people who were interned came out before Fascism even got hold in the country ... just humble workers.

Being labelled 'Fascist' would have come as a shock to many Italians who may have had some political awareness but did not associate any Italian feelings they held as implying they supported Fascism. Sam's comment suggests he was unaware of the extent to which expressing 'Italian' sentiments

${ }^{91}$ David Henderson, "A Travesty of British Justice? Appealing against Internment during the Second World War", Australian Journal of Politics and History, Vol. 65, 1 (2019), pp.69, 73-74.

92 Report, Cairns Police District, 27 February 1942, NAA, BP242/1, Q16274. 
was construed as pro-Fascist behaviour at the time. Internment had a nationalizing effect on some, particularly through the regular newspaper readings and patriotic celebrations. ${ }^{93}$

Although Sam said his father never complained about his internment, his own sense of the injustice perpetrated on Salvatore (and others) became clearer as a result of reading the archival files, a confronting experience in light of his own memories. Beforehand he had understood, from his father, that the internment was nothing particularly personal, just that Australians thought Italians were bad people, being the enemy in wartime. But Salvatore's being listed as "a wanted man" in the Queensland Police Gazette, and repeatedly labelled "Fascist" in other documents, amounted, in Sam's eyes, to his being depicted as 'a criminal', rather than an innocent worker wanting to protect his family and a larrikin who had outsmarted the local police. So the injustice became a painfully personal matter.

Sam's reactions highlight how difficult it is for family members not to take issue with such records. When reading something that is exceptionally personal and conflicts with lived experience, family members may feel affronted because of the disparity between the 'evidence' and personal memories. If the government's 'enemy alien' stigmatized Italians and others as potential saboteurs, the Ragonesi family's narratives rescued a larrikin and outcast; if the official and public image of Italian migrants reflected the Ferry Report's criminal Southern Italian peasant (with contemporary derogatory meaning), the Ragonesi family memories recalled an illiterate but honest farmer; if political and public opinion created the Fascist, the Ragonesis only saw a reliable, working, family man dedicated to Australia with no political interest in Italy's regime. There were several discrepancies between the archival records and Sam's memories - in relation to Salvatore's desire to naturalize despite his lack of English proficiency, his alleged Fascist sympathies, the circumstances in which he came out of hiding. These errors, together with the indelible image of his passport photo used as a mugshot, for Sam put a slight on his father's character that the public record rendered official and lasting.

The "myths, images and ideologies" which Finnegan refers to as characteristic of family and community oral histories cannot be seen in isolation from official wartime policies and records, and public attitudes. Australia's internment episode during World War II was complex, generating multiple perspectives, experiences and memories for those who lived through it. Focussing on the Ragonesi family's experiences of internment allows an exploration of nuanced social, cultural and family layers hidden from the public, written record, suggesting the importance of collaborations between archival institutions and the general public. Our recapturing of one internee's life story through his son's memories and engagement with the official records illustrates the intergenerational impact of internment and the potential of this approach for bringing this "dark underside" of Australia's wartime history to a wider audience through the second generation's oral life stories.

93 See Sardi, The Internment Diaries, pp. 44, 56, 71, 81-82. 